\title{
AZ ÓVÓKÉPZÉS ÉS A BOLOGNAI FOLYAMAT
}

\section{KOVÁCSNÉ BAKOSI ÉvA}

\author{
a Debreceni Egyetem Gyermeknevelési és Felnőttképzési Karának \\ föiskolai tanára
}

\section{A felsőoktatás átalakulásának lépései}

2006-ot írtunk, amikor a hazai felsőoktatásban, s így a pedagógusképzésben is, áttértünk a kétciklusú - egyes megközelítésekben a háromciklusú - képzésre a „bolognai folyamat" részeként. Bologna megmozgatta az egész magyar pedagógusképzést. Mindenki előtt világos volt, hogy a bevezetendő képzési struktúra hosszú távra meghatározza az egész hazai pedagógusképzés jövőjét. A bolognai folyamat az óvodapedagógus képzésben is egy fontos állomásnak tekinthető. Erre az állomásra úgy érkeztünk meg, hogy a továbbutazáshoz nem volt üres a tarisznyánk. Az egyik rekesz tele volt a nemzetközi összehasonlításban is ismert, elismert szakmai értékeinkkel, a másik rekeszben meg helyet kértek maguknak a megoldásra váró szakmai kérdések.

A felsőoktatás képzési struktúrájának átalakítása akkor indult el, amikor még alig fejeződött be az intézmények szervezeti átalakítása. A cél a lineáris képzési rendszer megteremtése volt. A lineáris rendszer rugalmasabb, átjárhatóbb, a tömegoktatás és az elit képzés igényeit együttesen jól tudja kezelni, a töredék tanulmányokat is elismerhetővé teszi, költséghatékonyabb. A master és a $\mathrm{PhD}$ fokozat külföldön is megszerezhető, illetve a külföldiek hazai felsőoktatási intézményt választhatnak tanulmányaikhoz. E nagyszabású vállalkozás abba a folyamatba illik, amelyet a differenciálódás, diverzifikálódás és a homogenizálódás együttes tendenciái jellemzik. Egyetértünk Hrubos Ildikóval, aki szerint az összehangolásra helyeződött a hangsúly (Hrubos, 2007).

Az összehangolásra már az 50-es évektől voltak kísérletek, de leginkább az 1989-ben, Bolognában kiadott Magna Charta hatott serkentőleg a folyamatra. Fordulatot 1998 hozott, amikor is a Sorbonne Nyilatkozat megfogalmazta az ún. Európai Felsőoktatási Térség létrehozásának igényét.

A Bolognai Nyilatkozat (32 ország) kiemelt figyelmet szentel az európai felsőoktatás nemzetközi versenyképességének fokozására, az európai kultúrának a világ más régióira ható vonzerejének növelésére, éppen a felsőoktatás által. A fejlesztés hat fö területét határozták meg: (1) összehasonlítható fokozatokat adó képzési rendszer bevezetése; (2) alapvetően két fö cikluson alapuló képzési rendszer kialakítása; (3) kreditrendszer bevezetése; (4) hallgatók, oktatók és más egye- 
temi munkatársak mobilitásának elősegítése; (5) összehasonlítható kritériumrendszer a minőségbiztosításban; (6) európai vonatkozások beépítése a képzési rendszerbe (Hrubos, 2002).

Újabb elvek megfogalmazására került sor 2001-ben Prágában:

- élethosszig tartó tanulás, tudásalapú társadalom és gazdasági prosperitás megvalósításával a társadalmi kohézió erősítése és az élet minőségének javítása;

- a hallgatók fokozottabb bevonása a munkába, a döntés-előkészítésbe;

- az európai felsőoktatás vonzerejének, versenyképességének növelése.

A Bolognai Nyilatkozat - állásfoglalás az Európai Felsőoktatási Térség létrehozása mellett - döntő szerepet vállalt a társadalmi, kulturális és gazdasági fejlesztésben, a felsőoktatási hallgatók és a munkavállalók mobilitásának elősegítésében. Ebből következően a hazai átalakítás négy deklarált funkcióját a felkészités alábbi területeire terjesztették ki:

- az életen át tartó tanulás,

- a mester- és a PhD szintű képzés,

- az európai polgári lét,

- a közvetlen munkaerö-piaci kimenet.

Az átalakulás három területen indult el: a) a duális modell helyett áttérés a lineáris képzési struktúrára; (A lineáris képzésre való áttérés alapelemei adottak voltak, bár szakterületenként eltérő igények fogalmazódtak meg.) b) a Kredit- átviteli Rendszer bevezetése, amely a struktúra átalakítás folyamatában már megkezdődött; c) a minőség fejlesztése, erröl a felsőoktatási törvény rendelkezett. (Egyebek között megalapításra került a Felsőoktatási Minőségi Díj.)

A Bologna koncepció kidolgozására, szakmai vitájára, egyeztetésre bizottságokat hoztak létre. A képzési rendszer szabályozása hatályba lépett. A MAB kidolgozta a szükséges kritérium rendszert. A szakok kimunkálására konzorciumok jöttek létre, megjelentek a szakok Képzési és Kimeneti Követelményei (KKK-k), majd elkészültek a szakalapítási kérelmek. Az intézmények akkreditálásra benyújtották szakindítási kérelmeiket. Pályázatokat írtak ki - HEFOP - tanterv-, tananyag-fejlesztési céllal. Megtörtént a tantervek áttekintése, értékelése a pályázati vállalásnak megfelelően.

Az óvodapedagógus képzésben is megkezdődtek, lezajlottak az átalakítás folyamatai. A bolognai folyamatot az óvóképzés nézőpontjából lehetne oktatásszociológiai, oktatás-irányítási, felsőoktatás-gazdasági és sok más egyéb szempontból elemezni. Ez alkalommal csupán arra térek ki, hogy a bolognai átalakuláskor milyen szakmai problémák megoldása várt a szakterületre, milyen új elemek épülhettek be a képzési rendszerbe a változás következtében, $\mathrm{s}$ megpróbálok néhány perspektivikus gondolatot megfogalmazni. 


\section{A változások szükségessége - a szükséges változások}

Kijelenthetjük, hogy az óvodapedagógus képzésben változásra akkor is szükség lett volna, ha nincs „Bologna”. A szakterületen már 2003-ban összefoglaltuk a teendőket. Nehéz lenne elképzelni, hogy most, amikor minden képzési szinten - megvizsgálva az egyes szakokat - a reformtörekvésekkel egyidejüleg azok tartalmi megújulását is tervezik, az óvóképzés, a fejlődést hosszútávra meghatározó korszerüsítéséről lemondjon. Szakmai indokok és a sikeres nemzetközi példák alapján az óvodapedagógus képzés jövőjét s annak fejlődését a strukturális változással egyidejü tartalmi megújulással együtt tudjuk elképzelni.

Az óvóképzés tartalmi és szervezeti modernizációjára megértek a feltételek. Ha nem lenne „Bologna”, akkor is rá kellene irányítani a döntéshozók figyelmét a következőkre:

- A gyermekközpontúság érvényesitése: az eddiginél is célirányosabb és alaposabb felkészítés szükséges mind elméleti, mind gyakorlati szempontból. Ez jelenti a 3 évestől a 7-8 évig terjedő korosztály ténylegesen is differenciált fejlesztésére, a hátrányos és halmozottan hátrányos helyzetűekkel való egyéni foglalkozásra, a magatartás és tanulási problémák felismerésére, kezelésére, az integrált nevelésre, az inter- és multikulturális nevelés újszerü és tömegesen jelentkező feladataira, az alapozó funkció differenciált teljesítésére való célirányos felkészítést. Ténylegesen is középpontba szükséges helyezni a gyermekközpontú nevelés müvészetének elsajátitását.

- Az óvoda diszfunkcióinak elháritása: ezek között még mindig igen nagy súllyal van jelen a következő fokozatnak (az óvoda esetében az iskola első osztályainak) való megfelelés kényszere; az óvoda nem helyettesítője a családi nevelésnek, hanem az együttmüködés színtere; s nem szabadna pénzügyi szempontok érvényesülni a gyermekek különfoglalkozásai terén.

- Az alapozó funkció érvényesitése: ez a funkció megkívánja a gyermeki személyiség jellemzőinek és fejlődésének egységben látását, ennél fogva szükséges az óvodáskor előtti időszak és a 7-8 évesek alaposabb megismerése elméleti és a gyakorlati szempontból egyaránt.

- Felkészités a hivatás bövülö szakmai kompetenciáira: nagyobb hangsúlyt kell kapnia a képességfejlesztésnek, ezáltal a gyakorlatnak (affektív hatás, csoportdinamika, önszabályozás, reflektív magatartás, játszóképesség, a segítés képessége, informatikai kompetencia stb.).

- A gyakorlásra megállapitott időkeret felülvizsgálata: célszerü elemezni a tréninghelyzetek és praxishelyzetek arányait, tartalmát, a személyes jellegü gyakorlati tudás kialakítási folyamatát $\mathrm{s}$ a kompetens személyek együttmüködésének lehetőségeit. Nagyobb figyelmet kell kapnia a képzésben a „pszichológiai immunrendszer” erősítésének, a pszichikus egészség kifejlesztésének. 
- Az intézményi kapcsolatrendszerre felkészités kiegészitése: kiegészitésre szorul az intézményi kapcsolatrendszerrel (partnerekkel) összefüggő elméleti és gyakorlati felkészítés (megelöző periódus: bölcsőde; következő intézmény: iskola; szakmai szolgáltató intézmények és szakszolgálat). Itt utalunk arra a Magyar Pedagógiai Társaság Kisgyermek-nevelési Szakosztálya által szorgalmazott igényre, amely szerint „a 0-3 éves korosztály nevelésével foglalkozó szakemberek is integrálódjanak az új felsőoktatási rendszerbe.” Jogosnak ítélhetjük meg, hiszen a gyermekek gondozása és a nevelő hatások közvetítése szinte elválaszthatatlan egymástól. Az intézményes keretekben (bölcsődében) folyó kisgyermeknevelés és gondozás terén a nevelö funkció erősödött. A nevelöi szerepre való alaposabb szakmai felkészítést a szakterület megfelelő érvekkel alá tudta, illetve tudja támasztani. Így került kidolgozásra és elfogadásra a Csecsemő- és gyermeknevelö BA szak, amelynek révén a fenti igények teljesülhetnek, a szak az óvodapedagógus-tanító képzési ághoz tartozik.

- A családdal való együttmüködés differenciáltabb alapozása: a képzésben a családdal való együttmüködésre több diszciplínát is magában foglaló (családpedagógia, családszociológia, esélypedagógia) elméleti alapozással szükséges felkészíteni.

- Új tantárgyi struktúrák kialakitása: az egyes diszciplínák új tudományos eredményei tovább differenciálják az egyes tantárgyak tartalmát: az új tartalmak új tantárgyi struktúrák kialakítását teszik szükségessé, várhatóan növekvő időkeretet igényelve. (A jelenlegi képzési időt még egy korábbi, a normatív pedagógiai felfogás időszakában állapították meg, ami nem igényelte a tananyag folyamatos korszerüsítését.)

- Felkészités az óvodapedagógusok új feladataira: a minőségfejlesztés, a mérés és értékelés, a marketing és PR, a helyi programkészités és -fejlesztés, az inter-, illetve multikulturális nevelés, az inkluzív nevelés, projekt készítés, médiapedagógia, szakmai karrierépítés, verseny a munka világában - mind-mind olyan feladat, amelyre már a pályakezdés szakaszában felkészültnek kell lenni. E kérdésekkel a jelenlegi alapképzésben csak minimális órakeretben lehetséges foglalkozni. Ebböl is következik, hogy a szakirányú továbbképzések tartalma is felülvizsgálandó: mi az, amit ma már nem lehet úgy kezelni, hogy az az alapképzésből kimaradt. A szakirányú továbbképzések egy része beépítendő az alapképzésbe.

- Az oktatás és gyakorlati képzés szervezeti formáinak és módszereinek korszerüsitése: a korszerü szervezeti formák és az interaktív módszerek (laboratóriumi munka, cselekvésközpontú projektek, önreflexió, problémafeladatok stb., több önálló, egyéni és páros kutatómunkára, megfigyelésre épülő feladat, az elmélet és gyakorlat még jobban érvényesített kapcsolata, interaktív tanítási technikák, esetmegbeszélő órák, szupervízió, tanács- 
adási megbeszélés, szimuláció stb.). időigényesebbek, kisebb csoportokat igényelnek. Esetenként lassúbb a haladás, az oktatásszervezés rutinos megoldásain változtatni kell, ez többletráfordítást igényel, de a befektetés megtérül.

- Szükséges a mentorhálózat folyamatos fejlesztése: sem a gyakorlati képzés, sem a kezdő pedagógusok gyakorlati tevékenysége nem nélkülözheti a (széles értelemben vett) mentorokat. Képzésük, továbbképzésük régóta megoldásra váró feladat.

- A képzés zsákutcás jellegének megszüntetése: az óvodapedagógus képzés felsőoktatásba illeszkedése, az óvodapedagógus pálya presztízse és a felsőfokú oklevéllel rendelkező óvodapedagógusok személyes érdeke egyaránt azt igényelte, hogy szünjön meg a képzés zsákutcás jellege: az itt végzetteknek is legyen lehetőségük továbbhaladásra a felsőoktatás keretén belül.

Ezek voltak a mintegy évtizeddel ezelőtti helyzetelemzés legfontosabb megállapításai. S mivel széles szakmai konszenzus övezte a feladatok ilyenfajta számbavételét, a folyamatos korrekciók, illetve a 2006-os új képzési programkidolgozásában mintegy iránytüként, vezérfonalként müködött. Ezért számos felkészítési feladat helyet is kapott, de a változás a várakozásnak csak részben felelt meg.

\section{Az óvodapedagógus képzés illeszkedése a lineáris képzési rendszerbe 2006-tól}

Az óvodapedagógus képzés gyakorlatias, hagyományosan jó színvonalú képzési rendszere nem változott, ugyanakkor az itt kiválónak bizonyult hallgatók saját intézményükben, esetleg más egyetemen haladhatnak tovább a mester és $\mathrm{PhD}$ fokozatig. Tehát a zsákutcás jelleg megszünik.

Cél volt a rugalmas, szintek és irányok közötti átmenetet biztosító rendszer kiépítése:

- FSZ: felsőfokú szakképzés (Csecsemő- és gyermeknevelő, gondozó)

- BA alapképzés: 6 félév, 180 kredit.

- MA: neveléstudományi mester szak - a kora gyermekkor pedagógiája szakirány

Besorolás: Tudományág - társadalomtudomány, ezen belül neveléstudomány, pedagógusképzési terület - óvodapedagógus, tanító képzési ág.

Európai összehasonlításban az óvodapedagógus képzés - csekély kivétellel felsőfokú jellegủ, tanulmányi ideje általában 3 év, de van ennél hosszabb képzési idő is. Egyetemen, illetve egyetemi szintü intézményekben képzik az óvodapedagógusokat Finnországban, Spanyolországban, Olaszországban, Görögországban, Franciaországban, az Egyesült Királyságban. Biztosított a teljes körü továbbhala- 
dás pl. Finnországban az óvodapedagógus MA-ba, de a képzés két ciklusra tagolódik, s a BA-val is el lehet helyezkedni óvodapedagógusként (Ladányi, 1997).

Az előkészületek folyamán volt egy pillanat, amikor az egységes alsó fokú pedagógusképzés gondolatára alapozó képzési program az óvóképzésben is lényeges minőségi változás hozott volna 8 féléves képzési idővel és 240 kredittel. De ezt az elképzelést - közel a célhoz - nem tudtuk sikerre vinni. Helyette az első BA-s képzési és kimeneti követelményben 180+30 kredites, 6 féléves képzési keretet adott a szaknak. Ez adott némi fejtörést, hiszen hat félévbe kellett elhelyezni 7 féléves kreditmennyiséget. Így is készültek el az indítási kérelmek. Módosítani kellett, mert a 30 kreditet időkeret és finanszírozás nélkül nem lehetett kezelni: visszaállt az eredeti képzési idő és az annak megfelelő kreditszám: 6 félév 180 kredit. A tantervalakító munka ezen az alapon folytatódott tovább.

\section{Változások, új elemek a képzésben}

A képzési szintek egymásra épülnek (legalsó szint az FSZ, majd BA, MA, PhD tanulmányok következnek. Minden szinten biztosított a szaknak megfelelő egyenes továbbhaladás). A kreditek beszámíthatóak.

Nyíltabb verseny - az indíthatja a szakot, akinek megvannak az elöírt feltételei. A képzési helyek számát illetően nincs korlátozás. A folyamatosan csökkentett finanszírozott létszámon egyre több képzési hely osztozik.

Kompetencia alapú a Képzési és Kimeneti Követelmény (KKK), amely tükrözi a közoktatás változó igényeit és szükségleteit.

A képzéssel foglalkozók nehezményezése ellenére a nemzetiségi óvodapedagógus képzés szak helyett szakirány lett, s ez azt jelentette, hogy a nemzetiségi képzés képzési idejében is szükült.

Az átjárhatóság, a mobilitás megkönnyítésére HEFOP pályázat keretében széleskörü együttmüködésben került ki-, illetve átdolgozásra az óvodapedagógus szak képzési programja (új tanegységek beemelése, tantárgyi tartalmak aktualizálása, kötelező, kötelezően választható és választható stúdiumok rendszerének alkalmazása). Ezzel megtörtént a tantervek összehangolása. Általános és speciális ismereteket helyeztünk el a tantervben: alapozó és a szakképző szakaszra bontottuk a képzést. Megerősítettük a gyakorlatorientált jellegét, megemeltük az összefüggő gyakorlat idejét 6 hétről 8 hétre. Horizontális szempontokat jelenítettünk meg a képzési tartalomban: a fenntartható fejlődés és az esélyegyenlőség szempontjait érvényesítettük ily módon.

A képzési hangsúlyokból adódó eltérések azért intézményenként megvannak, sajátos intézményi arculattal. A szarvasi intézmény olyan sajátos feladatokra is felkészíti a hallgatókat, mint a nemzetiségi képzés, a mentálhigiéné és a gyógytestnevelés. Hajdúböszörmény a játék pedagógiájára fordít igen nagy gondot, s két választható programot is kidolgozott (Lépésről lépésre és a Vidámság Háza). 
A soproni föiskola sajátossága, hogy ők a reformpedagógiákkal és az irodalmi neveléssel foglalkoznak többet, illetve nemzetiségi képzésnek is helyet adnak. Onnan a Freinet-program és az Óvodai nevelés játékkal, mesével óvodai program ismert. A budapesti karon a fejlesztőpedagógia jelenik meg magas szinten, és ott ezt építik be a hallgatók pályára történő felkészítésébe.

A lineáris rendszerre történő átmenet zökkenőmentes volt, hiszen mi nem álltunk olyan nehézséggel szemben, mint a tanárképzés, ahol az öt éves képzést kellett átformálni 3+2évesre, illetve BA+MA-ra. A munkaadók részéről sincs semmilyen dilemma (mint ahogy sok BA-s diplomával kapcsolatban ez felmerül), hiszen az óvodapedagógusi diploma alapfokozatot és egyben pedagógus szakképzettséget is ad.

A kétlépcsős szisztéma azonban felvetette azt a kérdést, hogy milyen MA-beli folytatást biztosítson a rendszer. Lehet-e szükebb szakterületi továbbhaladás, azaz lesz-e óvodapedagógus MA vagy ez a szak más képzési rendszerbe illeszkedik-e be. Számos európai gyakorlattól eltérően (az élvonalban lévő finnek, svédek, továbbá olaszok, franciák) nem kapott kellő szakmai támogatást az óvodapedagógusi MA létesítése. Persze, van példa hazai megoldásunk nemzetközi megerősítésére is, mely szerint a neveléstudomány mester szakon, annak szakirányában folytathatják tanulmányaikat az óvodapedagógusok.

A nemzetközivé válás folyamatában technikai változás a dokumentációban a kétnyelvü diploma, illetve diploma melléklet kiadása. A tanterv, a tantárgyi programok angol nyelven is elkészültek.

Egyre bővülő, erősödő mobilitásnak vagyunk tanúi. Bár ahhoz, hogy a felsőoktatás a maga lehetőségeit érvényesítse, illetve ki tudja használni, ahhoz a bemenetnél kellene jóval erősebb nyelvi felkészültséggel érkezniük a hallgatóknak. De így egyre több intézményben jellemző a kétoldalú szerződésekkel támogatott oktatói és hallgatói mobilitás. Ugyanígy az Erasmus mobilitási program is kihasználható anyagi forrást biztosít a külföldi szakmai és nyelvi, kulturális tapasztalatszerzésre. A kívánt és szorgalmazott mobilitást, mint az európaiság egyik jellemzőjét tovább nehezíti az érkező hallgatóval való foglalkozás, az idegen nyelvü kurzus biztosítása, de különösen a gyakorlatban történő foglalkoztatása. Ez alól talán csak a nemzetiségi képzéssel foglalkozó karok a kivételek.

Korszerü informatikai háttér segíti a képzést és az adminisztrációt, az ETR (Egységes Tanulmányi Rendszer) vagy a NEPTUN rendszer. Az információs rendszer részévé váltak a folyamatosan fejlödö honlapok is.

A bolognai folyamat tovább növelte a versenyt, $\mathrm{s}$ a minőségi képzés egyértelmü követelménye mellett erőteljesebb marketing és PR tevékenységre készteti, illetve kényszeríti a versenytársakat. Az átrendeződés miatt igen nívós szakmai mühelyek kerülnek nehéz helyzetbe. 2008-ban pl. a 876 hallgatót 12 képzési helyre vették fel, ebböl 40\%-ot Budapestre, illetve Pest közelbe. A megosztott piac miatt új képzésekre irányult a figyelem, az erőforrások tagolódtak, s a korábban egy-két szakra való koncentrálás már a múlté. 
Az óvodai nevelésre és óvóképzésre vonatkozó kutatási aktivitásról elmondható, hogy az sok esetben a $\mathrm{PhD}$ fokozat megszerzéséhez kapcsolódik. A lineáris képzési rendszerre történő áttérést követően is jellemző az egyes képző intézmények sajátos, speciális kutatási területeinek, témáinak személyes meghatározottsága. Többnyire ez adja meg sajátos kutatási profilját is az adott intézménynek.

Mint ismert, a MAB egyre magasabb színvonalú humánerőforrást kíván az új szervezésü képzésekhez. E törekvés el is fogadható. Az viszont már sok nehézséget okoz, hogy igen nehezen, lassan és igen alacsony létszámban végeznek oktatók a DLA képzésben, továbbá a testnevelés és a gyógypedagógia területén, de nincs túlképzés a pszichológia területén sem.

Feltehető a kérdés: felkészülttebb, jobb óvodapedagógusokat képezünk-e? Mindenképpen ezt a törekvésünket fejezték ki a modulok, tantárgyelemek megújított tartalma, a képzési metódus korszerüsítése, a gyakorlati idő növelése és a hallgatói önállóság fokozása. Ezeken kívül:

- a nyelvi követelmények szintjének emelése a nemzetközi mobilitást segíti;

- a specializáció, a szakirány beillesztése:

- magasabb szintü, elmélyültebb felkészüléshez vezet;

- egyéni érdeklődés kielégítésével növekszik a hallgatói motiváció;

- még nagyobb figyelemmel fordulunk a tehetségek felé, segítjük az MA-ba való továbbhaladást, illetve orientációt. A mester szintủ képzés várhatóan növeli majd a szak presztízsét és a végzettek felkészültségi nívóját;

- figyelünk az önálló munka fokozására, a pedagógiai valóság problémahelyzetein keresztül a gyakorlatközpontú felkészítésre, ezzel az önállóság, szakmai alkotóképesség mind teljesebb kibontakozására;

- az önértékelésnek, önreflexiónak mind nagyobb teret biztosítunk;

- a felkészítés során a gyermekek megismerésére és az egyénre ható, az ahhoz igazodó hatásrendszer érvényesítésére, az egyénre figyelő nevelői magatartás kialakítására különös gondot fordítunk;

- igyekszünk elérni a minőségelvü gondolkodással való azonosulást.

\section{Perspektivikus feladatok}

A 6 féléves BA képzést természetesen alapképzésként értelmezzük, miközben felkészitünk az MA folytatására. Eközben speciális témakörök felvételére és teljesítésére is sor kerül. Erről inkább azt lehet mondani, hogy a hallgató ízelítőt kap a későbbi választáshoz, illetve elemi tájékozottságra tesz szert (fejlesztőpedagógia, sajátos nevelési igényü gyermekek nevelése, pedagógiai mérés, értékelés stb.). Ezekre és további speciális feladatra alaposabb elméleti és gyakorlati felkészítés szükséges, vagy az MA továbbhaladásban vagy a BA képzés keretében meghosz- 
szabbított specializáció, esetleg szakirány keretében további két félévben. Megfontolható lehet a tanárképzésben már bevezetett gyakorló félév is.

A korosztályi határok egyre mobilabbakká válnak. Jellemző a szélesebb korosztályi érintkezés, pl. az óvoda-bölcsőde típusú csoportszerveződésben, illetve az ovi-suliban, más néven óvoda-iskolában. Mindkét szervezeti forma képzésbeli megfontolásokat is felvet: mérlegelendő a párhuzamos képzés, illetve a kiegészítő képzés, esetleg támogatott újabb diplomás képzés lehetősége.

A mentorok mester szintủ végzettsége fokozatosan elérendő követelmény lehet - elöször a gyakorló intézményekben, később a területi gyakorlaton is.

Távlati célunk az óvodapedagógusok MA továbbhaladásának biztositása saját szakterületükön. Ez nem beszükítés, csupán koncentrálás és hangsúlyos felkészítés az adott korosztály elméleti és gyakorlati problémáival való magasabb szintü foglalkozásra. Hasonlóan szerencsés lenne a $\mathrm{PhD}$ képzésben is programot müködtetni.

A nyelvi korlátok legyőzésével idegen nyelvü kurzusok hirdetése lehetőséget teremthet az európaiság, a nemzetköziség szélesítéséhez.

Végezetül utalunk azokra a körülményekre, feladatokra, amelyek az intézményi és képzési szerkezet átalakítás közben kialakultak a képzőhelyeken. Megszoktuk a versenyt, előnyei mellett megtapasztaltuk hátrányait is. Elfogadtuk a minősítési, hitelesítési eljárás bevezetését, a vele járó többletfeladatot, a szakalapítás, indítás, a kar- és intézmény, a kapacitás akkreditáció procedúráját. Alkalmazkodtunk a szinte évenként módosuló felvételi rendszerhez. Tudtuk kezelni a támogatási formájában folyamatosan változó felnőttképzés visszatérését. Megtanultunk: pályázatot írni, projekt terveket készíteni, bonyolult adminisztrációs követelményt teljesíteni; saját bevételi forrásokat felkutatni; partnereinkkel együttmüködni, kapcsolati tőkét teremteni; minőség kategóriákban gondolkodni; az egyre magasabb oktatói követelményeknek megfelelni; nemzetközi követelményekhez mérni magunkat. Ha mindezt összegezzük, elmondhatjuk, hogy az 50 éve felsőfokúvá vált óvóképzés igencsak dinamikus korszakát élte az utóbbi tíz évben. Utunkon eddig a nagy mesterek, az óvóképzés jelentős egyéniségei kísértek. Lassan elhagynak bennünket, elengedik kezünket. Már akiét meg tudták fogni, mert az intézmények egyre bővülö képzési kínálata miatt megosztottak lettünk, s szinte alig lehet olyan szakmai életutat felépíteni, amelyben az óvóképzéssel való foglalkozás kizárólagos. Ezen is változtatni szeretnénk.

Előadásomban az óvodapedagógus képzés és a bolognai folyamat viszonyát elemeztem. Tudjuk, Bologna nem oldott meg mindent, nem is tehette. A képzés szerkezetének megváltoztatása önmagában még kevés az oktatási rendszer kívánt fejlődéséhez. A képzés tartalmi, szerkezeti, metodikai fejlesztése párhuzamosan a mühelygyakorlattal és a hivatástudatot formáló belső erők intenzív mozgósításával - soha meg nem szünő feladat. A következő nagyobb évfordulón már a többciklusú képzési rendszer értékelésére kerülhet sor. 


\section{Irodalom}

Bolognai Nyilatkozat: http://www.edupress.hu/dokumentumok/Bolognai nyilatkozat.doc.

Falus Iván (2004): A pedagógussá válás folyamata. Educatio, 3. sz. 359-374.

Hrubos Ildikó (2002): A „,bolognai folyamat.” Kutatás közben 235. Oktatáskutató Intézet, Budapest.

Hrubos Ildikó (2007): A felsőoktatási rendszerek európai harmonizációja különböző nemzeti és intézményi megoldásokkal. In: Hrubos Ildikó - Tomasz Gábor (szerk.): A bolognai folyamat intézményi szinten. Felsőoktatási Kutatóintézet, Budapest, 14-56.

Kárpáti Andrea: Tanárképzés, továbbképzés - Magyarország Honlap. 2004. http://www.oki.hu

Ladányi Andor - Szőke Krisztina (2004): A pedagógusképzés a kétciklusú képzés rendszerében. Educatio, 3. sz. 406-414.

Ladányi Andor (1995): A pedagógusképzés minőségi fejlesztéséről. Magyar Felsőoktatás, 3. sz. 7-9.

Ladányi Andor (1997): A pedagógusképzés minőségi fejlesztéséről. Új Pedagógiai Szemle, 9. sz. 3-13.

Polónyi István (2004): A hazai felsőoktatás demográfiai összefüggései a 21. század elején. Kutatás Közben 255. Felsőoktatási Kutatóintézet, Budapest.

Szabó László Tamás (1996): Modernizáció kérdőjelekkel. Pedagógusképzés és továbbképzés. Kutatás közben. 210. Budapest. 